\title{
Compatibility and performance of susceptible tomato cultivars grafted onto bacterial wilt (Ralstonia solanacearum) resistant rootstock
}

\author{
Kanyua Stella1 ${ }^{*}$, Mwangi Maina ${ }^{1}$ and Mbaka Jesca. ${ }^{2}$ \\ ${ }^{1}$ Department of Agricultural Science and Technology, Kenyatta University, Kenya. \\ ${ }^{2}$ Horticulture Research Institute, Kenya Agricultural and Livestock Research Organization, Kenya \\ *Corresponding author email: ignastella@gmail.com \\ Original submitted in on $12^{\text {th }}$ March 2020. Published online at www.m.elewa.org/journals/ on $31^{\text {st }}$ March 2020 \\ https://doi.org/10.35759/JABs.147.3
}

\begin{abstract}
Objective: Tomato (Solanum lycopersicum L.) belongs to the Solanaceae family and currently is one of the most important vegetable crops. Bacterial wilt, caused by Ralstonia solanacearum is a soil borne disease of tomato causing significant economic damage on tomatoes, tobacco and potatoes. Bacterial wilt is difficult to manage because the pathogen can survive in soil for long periods in association with a wide range of crops such as pepper, potato, capsicum, eggplants and weeds such as Jimson weed and nightshade. The objective of this study was to determine compatibility and performance of susceptible tomato cultivars grafted onto bacterial wilt resistant rootstocks.

Methodology: Scions from susceptible tomato commercial cultivars (Anna F1 and Cal J) were grafted onto rootstocks of Eggplant, Sodom apple and tomato cultivar Mt56 that were determined to be resistant to bacterial wilt in a previous study. Cleft grafting technique was used in the experiment. Data on compatibility was assessed daily to check on the healing of the graft union and number of established plants. The grafted plants were considered compatible if $67 \%$ of the grafted plants had healed and growth established fourteen days after grafting. Data were subjected to ANOVA using GenStat version 15 and significantly different treatment means separated using LSD at $P \leq 0.05$.

Results and application: The grafted plants were compatible at varying rates, that is Mt56 + Anna F1 (93.30\%), Mt56 + Cal J (76.7\%), S. melongena + Anna F1 (96.7\%), S. melongena + Cal J (83.3\%), S. incarnum + Anna F1 $(73.3 \%)$, and S. incarnum + Cal J (100\%). It was concluded that tomato scions and the botanically related wilt resistant rootstocks are compatible. All the grafted plants performed well except those on Sodom apple rootstock whose stem did not expand at the rate as the scion stem. It is recommended that the proven resistant rootstocks be deployed to tomato farmers for use in tomato grafting and subsequent increase in their production.
\end{abstract}

Key words: Grafting, Compatibility, Performance, Bacterial wilt 


\section{INTRODUCTION}

Tomato (Solanum lycopersicum L.) belongs to the Solanaceae family and is currently one of the most important vegetable crops globally and in Kenya. Tomato fruit is an essential part of daily alimentation and can be consumed either fresh, cooked or processed, which is characterized by high nutritional value. It contains carbohydrates, mineral salts, vitamins and organic acids of great nutritional importance (FAO, 2014). Globally tomato grows on an area of over 5 million hectares and annual production of up to 170 million tonnes averaging yields of 34 tones/ha. Locally, tomato was ranked first among the vegetables grown in the country; it is grown on an area of over 12 thousand hectares, with annual production of 670 thousand ton and average yield of 56.5 tones/ha (FAO, 2014).

Tomatoes have a high content of vitamin $\mathrm{C}$, carotene (vitamin A precursor), lycopene and xanthophylls. Consumption of the fruit decreases hypertension due to its potassium content (Ringer and Bartlett, 2007; Anderson et al., 2008). Lycopene acts positively in digestion preventing cancer of the digestive system, the prostate, the lungs, the uterus and the ovaries (Giovannucci et al., 1995; Gann et al., 1999; Bowen et al., 2002). The antioxidant is effective for preventing cardiovascular diseases (Omenn et al., 1996), atherosclerosis and blindness (Bernier and Lavoie, 2001a, 2001b). Moreover, tomato is a diuretic, thus it helps to eliminate toxins from the body (Livernais-Saettel, 2000). Tomato production in Kenya is currently highly intensive and continuous cropping is a common practice. Due to monoculture, incidence of soil borne bacterial wilt is significantly high.

Tomato performance has been on a decline due to biotic and abiotic stresses. Biotic factors, including soil-borne pathogens and nematodes, account for roughly one third of the yield lost, the rest is attributed to abiotic factors that include salinity, drought, flooding, waterlogging, heavy metal contamination, suboptimal temperatures and nutrient deficiencies, and toxicities (Savvas et al., 2010; Schwarz et al., 2010; Peleg et al., 2011; Spiertz, 2012). Grafting tomato cultivars onto resistant bacterial wilt (Ralstonia solanacearum) rootstocks has been tested to increase the performance on tomatoes.

Grafting is an asexual plant propagation technique that joins parts from two different plants so that they grow as a composite of parts from different plants (Bareja, 2011). Graft compatibility is the establishment of a successful graft union as well as extended survival and proper functioning of the composite, grafted plant. Taxonomic affinity is a prerequisite for graft compatibility. For successful graft union to form, the rootstock and the scion cambium must be well aligned and in contact with one another because if the diameter does not match, the graft takes longer to heal and the rootstock will slowly starve to death. The scion and the rootstock plants must therefore have the same stem diameters at the time of grafting (Sacha, 2011).

The effectiveness of grafting in imparting tolerance to vegetable crops against abiotic and biotic stressors has been attributed to several improved traits of grafted plants such as, more vigorous root system, improved water and nutrient uptake, enhanced photosynthetic efficiency and water relations, stronger anti-oxidative defence system, heightened hormonal signalling and large and long-distance movement of mRNAs, small RNAs and proteins (Albacete et al., 2015; Warschefsky et al., 2016; Kumar et al., 2017). These mechanisms influence both root and shoot functioning, and the interconnectedness of the factors implicated (rootstock, scion and environment) hide singular contributions to phenotypic adaptation (Warschefsky et al., 2016).

Homografts (autografts) are presumably always compatible (Mudge et al., 2009). In rootstock and scion belonging to the same botanical species (heterografts intraspecific grafts) are nearly always compatible, rootstock and scion belonging to different species of the same genus (interspecific grafts) are usually compatible, interfamilial grafts are essentially always incompatible and intrafamilial grafts are rarely compatible (Mudge et al., 2009). Heterografts compatibility examination should include homograft controls (Olmstead et al., 
2006; Flaishman et al., 2008; Kawaguchi et al., 2008), a requirement that is not always fulfilled (Guan et al., 2012). This study aimed to evaluate compatibility and performance of susceptible

\section{MATERIALS AND METHODS}

The experiment was conducted in a greenhouse at Kenyatta University Teaching and Research Farm. The seedlings for resistant rootstock (Eggplant, Sodom apple and tomato cultivar Mt56) and susceptible tomato cultivars (Anna F1 and $\mathrm{Cal} J$ for use as scions) were raised on prepared nursery beds. The rootstock seeds were planted $5-7$ days earlier than the scion. Both the rootstocks and scions were raised for one month depending on the plant type, growth rate of the plant and whether the plant was used as a scion or rootstock. After one month, the rootstocks were transplanted into polybags and were allowed to establish before grafting was done. Grafting was done when the resistant rootstocks were one month and scions were three weeks old. The resistant rootstocks were selected and tested in a previous experiment. After the selected resistant rootstocks attained 2-3 true leaves (Sacha et al., 2011) and before becoming woody, they were used to graft onto scions of tomato cultivars Anna F1 and Cal $J$. The sample size for the experiment was ten grafted plants in three replicates. The rootstocks and scions seedlings were cut cleanly between the cotyledon (above) and true leaves (below) at an angle of 45 degree above the cotyledon (Maribel and Paul, 2010) to reduce the likelihood of shoots (suckers) developing

\section{RESULTS}

Scions of the susceptible tomato cultivars Anna F1 and Cal $\mathrm{J}$ were successfully grafted onto the bacterial wilt resistant rootstocks. Three days after grafting, only scions of Anna F1 and Cal J grafted on Sodom apple (rootstock) had established, but this increased to more than $67 \%$ of the plants fourteen days after grafting. tomato cultivar grafted onto rootstocks that were determined to be resistant to bacterial wilt in a previous study.

from the rootstock. During grafting cleft technique was used and the grafting tapes were used to hold the graft union together. Throughout grafting, it was ensured that the rootstock and scion stems had similar diameter and their cambium layer well aligned and in contact with one another to ensure that the graft union did not take long to heal and the rootstock did not starve to death. The grafted plants were kept in the greenhouse and all agronomic practices such as watering, pests and diseases control and feeding were observed. Data on the number of the grafted plants that survived was recorded daily and data subjected to ANOVA using GenStat version 15. Significantly different treatment means were separated using $L S D$ at $P<0.05$. The grafted plants were considered compatible if $67 \%$ of the grafted plants had 'taken' fourteen days after grafting. After confirming compatibility, the grafted plants were then transplanted into the soil media ensuring that the graft union is above the soil line. During the growth of the grafted plants, plant performance in form of plant height, number of leaves, number of flowers and yield in grams were monitored weekly and data subjected to ANOVA using GenStat version 15 and significantly different treatment means separated using $L S D$ at $P \leq$ 0.05 .

Grafts combining Sodom apple (rootstock) + Cal J (scion) had the highest take $(100 \%)$ followed by Eggplant + Anna F1 (96.7\%), Mt56 + Anna F 1 (93.3\%) while the least take was Mt56 + Cal J (76.7\%) and Sodom apple + Anna F1 (73.3\%) (Figure 1). 


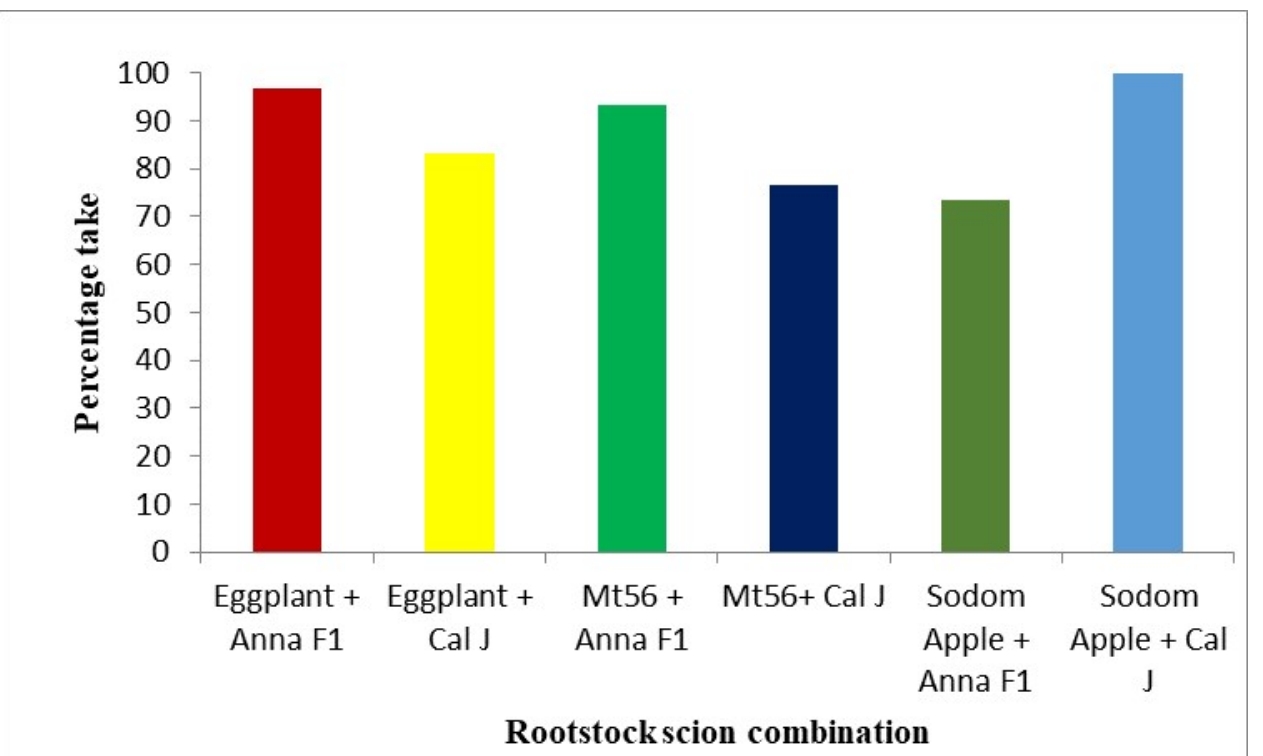

Figure 1: Proportion (\%) of grafted plants fully healed /established fourteen days after grafting.

The scions of Cal $\mathrm{J}$ and Anna F1 grafted onto Sodom apple established by the third day. Scions grafted onto Mt56 and Eggplant, were successful with 2/3 of the plants having established vascular connection within seven days. However, the stem of Sodom apple did not expand proportionately to that of Anna F1 and Cal J making it difficult for the rootstock to support the scions. At two weeks after grafting the seedlings of Sodom apple bent due to weakness of the stem at the graft union. Grafted plants of Eggplant and scions (Cal J and Anna F1) expanded at the same rate gaining an equal diameter that could adequately support the scion. The grafted plants were transplanted to the soil media twenty-one days after grafting when they had completely established. The height of the plants, number of leaves, number of flowers and yield in grams were evaluated and data recorded weekly. By the end of the eighth week after transplanting, the grafted plants of Mt56 + Anna F1 was the tallest $(110.5 \pm 20.98 \mathrm{~cm})$ while the other grafted plants did not show significant difference in height amongst themselves; Eggplant + Anna F1 attained $(78.25 \pm 22.91 \mathrm{~cm}), \mathrm{Mt56}+$ Cal J $(76.25 \pm 11.99 \mathrm{~cm})$ and Sodom apple + Anna F1 (68.75 $\pm 8.33 \mathrm{~cm})$ while Eggplant + Cal $\mathrm{J}(59.0 \pm 4.93 \mathrm{~cm})$ and Sodom apple + Cal J $(56.50 \pm 2.25 \mathrm{~cm})$ were shorter indicating reduced growth rate. The grafted plants of Mt56 + Anna F1 and Mt56 + Cal J had increased number of leaves from week 1 to 4 , which then reduced between weeks 4,5 , and 6 . An increase in the number of leaves was observed from week 6 to 8 . Eggplant + Anna F1 and Sodom apple + Anna F1 showed an increase in the number of leaves from week 1 to 8 but had no significant difference $(P \geq 0.05)$ between them. Eggplant + Cal J and Sodom apple + Cal J had fewer leaves with no significant difference $(P>0.05)$ compared to each other. All the grafted plants flowered from week 4 to 8 with Mt56 + Anna F1 achieving the highest number of flowers $(14.25 \pm 2.175)$ followed by Sodom apple + Cal J (12.5 \pm 1.258$)$ in week 7 . The same week Eggplant + Anna $\bar{F} 1$ had the least number of flowers $(6.5 \pm 4.093)$. By the end of week 8 , grafted plants of Mt56 + Cal $\mathrm{J}$ had the highest number of flowers $(16.5 \pm$ 8.737) followed by Mt56 + Anna F1 (16.0 \pm 0.816$)$. Eggplant + Anna F1 $(7.75 \pm 4.835)$ and Sodom apple + Anna F1 (13.75 \pm 3.119$)$ showed significant difference $(p \leq 0.05)$ in the number of flowers while Eggplant + Cal $\mathrm{J}(13 \pm 5.066)$ and Sodom apple + Cal J $(14.5 \pm 0.289)$ did not have significant difference in the number of flowers $(P \geq 0.05)$ (Figure 2). 


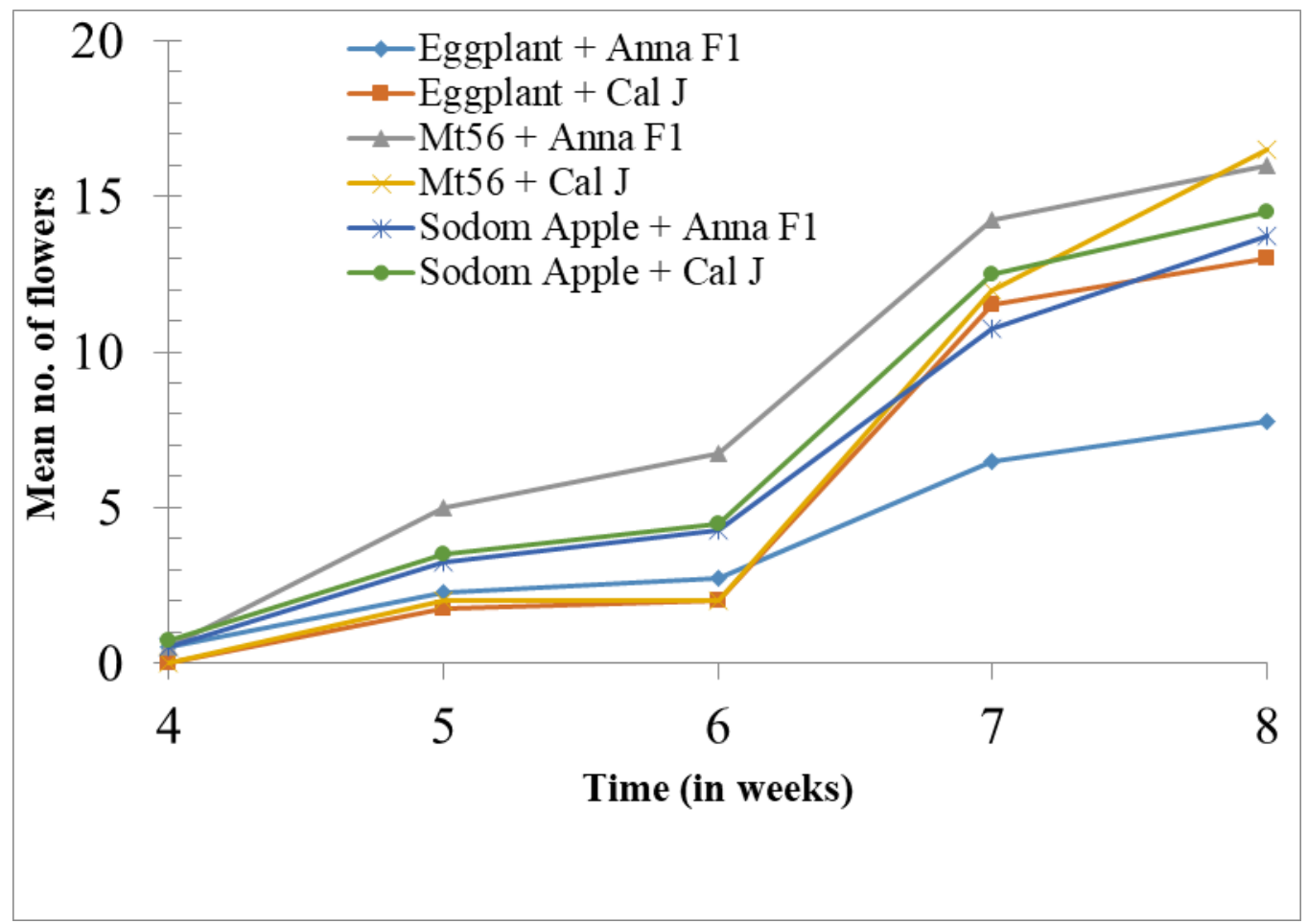

Figure 2: Mean number of flowers on tomato seedlings after transplanting.

Fruit development started in week 6 after transplanting. The tomato fruits were harvested twice a week for five harvestings and the yield (grams) recorded. Amongst the grafted plants, the highest yielding treatment was Sodom apple + Anna F1 (484 gms \pm 29.91), followed by Mt56 + Cal J $(435 \mathrm{gms} \pm 33.44)$ then Sodom apple + Cal J (420 gms \pm 21.15$)$ and Mt56 + Anna F1 (410 gms $\pm 27.3)$. The grafted plants that had least yield were Eggplant + Anna F1 (390 gms + 23.65) and Eggplant + Cal J (364 gms \pm 29.91$)$ (Figure 3). 


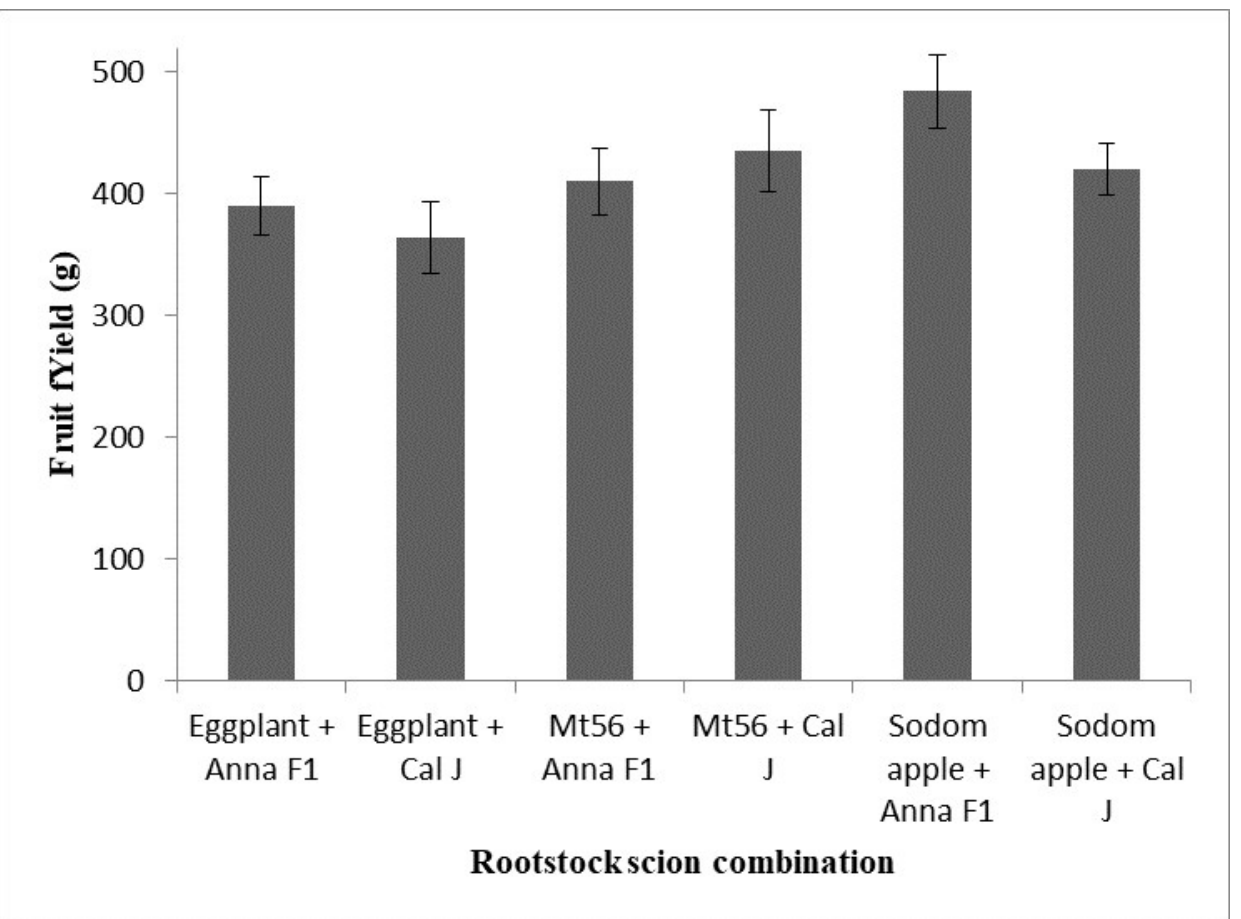

Figure 3: Mean yield of fruits produced by grafted tomato seedlings. Error bars $95 \%$ C.I.

\section{DISCUSSION}

Though Sodom apple (Solanum incarnum) is resistant/tolerant to Ralstonia solanacearum, and compatible with scions of Anna F1 and Cal J, the challenge with this species is that the seeds are not readily available in input supply shops (Agro - Vet shops), and thus have to be extracted from fruits. In addition, the fruits from this rootstock+ scion have not yet been proved edible since Sodom apple is known to be toxic. Furthermore, the experiment showed that when grafted, Sodom apple (rootstock) grows at a slower rate and has a narrower diameter than the scion, thus cannot fully support the growing plant. Tomato cultivar Mt56 is not yet being grown commercially because it does not meet the market demand in terms of quality and size, and its seeds are not readily available in the Kenyan market. Previous research confirmed its compatibility and good performance after grafting with susceptible tomato variety Onyx (Waiganjo et al., 2011). Various challenges are associated with grafting and cultivation of grafted seedlings. For example, there was production of adventitious roots from the scion by some grafted plants, which may be caused by poor alignment of vascular cambium and unequal diameter of both the rootstock and scion (Davis 2010). The roots, if allowed to grow into the soil, present the risk of re-infecting the plant as they by- pass the resistant rootstock, which could lead to the death of the entire plant. In this study, during transplanting, it was ensured that the graft union remained above the soil line as recommended by Black et al. (2003). Other challenges include lack of skilled labour for the grafting operations. Post graft handling of grafted seedlings for rapid healing is also a challenge (Jung, 1994). The results of this study confirmed there exists compatibility between susceptible tomato scions grafted onto bacterial wilt resistant rootstocks. Eggplant (Solanum melongena) and tomato Mt56 performed best with scions of Anna F1 and Cal J. The proven resistant rootstocks can be immediately deployed to propagators and tomato farmers for use in tomato grafting to control bacterial wilt and increase production. Due to the narrower stem diameter, it is evident that the Sodom apple rootstock cannot effectively support the grafted scions of the farmer preferred tomato varieties, unless staking is done. If staked, the fruits of tomato scions grafted on Sodom apple rootstocks would need further research to determine fitness for human consumption. Further studies on compatibility and performance of the resistant rootstocks when grafted with other solanaceous varieties is recommended, for wider application in bacterial wilt management. 


\section{REFERENCES}

Albacete, A., Martinez-Andujar, C., Martinez-Pérez, A., Thompson, A. J., Dodd, I. C., and PérezAlfocea, F. (2015). Unravelling rootstock $x$ scion interactions to improve food security. $J$. Exp. Bot. 66, 2211-2226. doi: 10.1093/jxb/erv027

Anderson J, Young L, Long E (2008). Potassium and Health. Food and Nutrition Series. Colorado State University 9355: 1-4

Bareja B. G. (2011). What is grafting? Uses in Addition to Plant Propagation. Crop Agriculture Review.-I. Retrieved on 19/5/2014.

Bernier V, Lavoie D (2001a). Le Lycopène: Un Antioxydant Très Puissant, Première Partie. Le Clinicien, Consultations en Nutrition 15 (11): 49-56

Bernier V, Lavoie D (2001b). Le Lycopène: Un Antioxydant Très Puissant, Deuxième Partie. Le Clinicien, Consultations en Nutrition 16(12): 53-60

Black, L. L., Wu, D., L., Wang, J. F., Kalb, T., Abbass, D. and Chen J. H. (2003). Grafting tomatoes for production in hot - wet season. International Cooperators Guide. AVRDC pub: $03-551$

Bowen $\mathrm{P}$, Chen L, Stacewicz-Sapuntzakis M, Duncan C, Sharifi R, Ghosh L, Ki m H, ChristovTzelkov K, Van Breemen R (2002). Tomato Sauce Supplementation and Prostate Cancer: Lycopene Accumulation and Modulation of Biomarkers of Carcinogenesis. Society for Experimental Biology and Medicine 227(10): 886-893

Davis, (2010). Techniques of grafting. aggie horticulture.tamu.edu/faculty/davis/.../M12_DA VI4493_00_SE_C12.pdf. Retrieved $09 / 07 / 2016$

FAO (2014). Food and Agriculture Organization of the United Nations. http://faostat.fao.org/ FAOSTAT: 2014

Flaishman, M. A., Loginovski, K., Golobowich S. and Lev-Yadun S. (2008). Arabidopsis thaliana as a model system for graft union development in homografts and heterografts. J. Plant Growth Regul.27 231-239 10.1007/s00344-008-9050.

Gann PH, Ma J, Giovannucci E, Willet W, Sacks FM, Hennekens CH, Stampfer MJ (1999). Lower prostate cancer risk in men with elevated plasma lycopene levels: results of a prospective analysis. J Cancer Res 59: 12251230

Giovannucci, E., Ascherio, A., Rimm, E. B., Stampher, M.J., Colditz, G. A, Willett, W. C. (1995). Intake of carotenoids and retinol in relation to risk of prostate cancer. J Natl Cancer Inst 87: 1767-1776

Guan, W., Zhao, X., Hassel, R. and Thies, J. (2012). Defense mechanisms involved in disease resistance of grafted vegetables. HortScience 47 164-170

Jung, M. L. (1994). Cultivation of grafted vegetables I. Current status, Grafting Methods and Benefits. Department of Horticulture, Kyung Hee University, Suwon 449-701, Korea

Kawaguchi M., Taji A., Backhouse D., and Oda M. (2008). Anatomy and physiology of graft incompatibility in solanaceous plants. J. Hortic. Sci. Biotech. 83 581-588.

Kumar, P., Rouphael, Y., Cardarelli, M., and Colla, G. (2017). Vegetable grafting as a tool to improve drought resistance and water use efficiency. Front. Plant Sci. 8:1130.

Lee, J. M., Kubota, C., Tsao, S. J., Biel, Z., Hoyos Echevaria, P., Morra, L., et al. (2010). Current status of vegetable grafting: diffusion, grafting techniques, automation. Sci. Hortic. 127, 93105. doi: 10.1016/j.scienta.2010.08.003 10.3389/fpls.2017.01130

Livernais-Saettel, L. (2,000). Tomatoes, Lycopersicon esculentum. http://www.dietobio.com/aliments/fr/tomate.ht $\underline{\mathrm{ml}}$

Maribel, $\bar{M}$. and Paul, W. B. (2010). Grafting Capsicum to Tomato rootstock; Journal of Young Investigators, Vol. 20, Issue No.2

Mudge K., Janick J., Scofield S., Goldschmidt, E. E. (2009). A history of grafting. Hortic Review. 35 437-493 $10.1002 / 9780470593776$.

Olmstead, M., Lang, N. S., Ewers F. W. and Owens, S. A. (2006). Xylem vessel anatomy of sweet cherries grafted onto dwarfing and non dwarfing rootstocks. J. Am. Soc. Hortic. Sci. $131577-585$.

Omenn, G. S., Goodman, G. E., Thornquist, M.D., Balmes J, Cullen, M. R., Glass A, Keogh, J. P., Meyskens, F. L., Valanis B, Williams, J. H., Barnhart S, Hammar, S. (1996). Effects of a combination of beta-carotene and vitamin $A$ on 
lung cancer and cardiovascular disease. $\mathrm{N}$ Engl J Med 334: 1150-1155

Peleg, Z., Reguera, M., Tumimbang, E., Walia, H., and Blumwald, E. (2011). Cytokinin-mediated source/sink modifications improve drought tolerance and increase grain yield in rice under water-stress. Plant Biotechnol. J. 9, 747-758. doi: 10.1111/j.1467-7652.2010.00584.x

Ringer, J. O., and Bartlett, Y. (2007). The Significance of Potassium. The Pharmaceutical Journal 278: 497-501

Sacha, J., Kreider, P. and Carol, M. (2011). Vegetable grafting (Eggplant and Tomatoes). Cvu.cahe.wsu.edu/CEP publications/FSO52E, pdf.pub; Washington State University. Retrieved 23/03/2014.

Savvas, D., Colla, G., Rouphael, Y. and Schwarz, D. (2010). Amelioration of heavy metal and nutrient stress in fruit vegetables by grafting. Sci. Hortic. 127, 156-161. doi: 10.1016/j.scienta.2010.09.011

Schwarz, D., Rouphael, Y., Colla, G., and Venema, J. H. (2010). Grafting as a tool to improve tolerance of vegetables to abiotic stresses: thermal stress, water stress and organic pollutants. Sci. Hortic. 127, 162-171. doi: 10.1016/j.scienta.2010.09.016

Spiertz, H. (2012). Avenues to meet food security. The role of agronomy on solving complexity in food production and resource use. Eur. J. Agron. 43, 1-8. doi: 10.1016/j.eja.2012.04.004

Waiganjo, M. M., Kambo, C., Kuria, S., Njeru, C., Mbaka, J., Gikaara, D., Amata, R., Erbaugh, M., Miller, S., Kyamanywa, S., Kleinhenz, M., Korach, J., Gathambiri, C., and Wepukhulu, S. (2011). On- farm grafting trials at Kangai tisa using new commercial tomato scion and wilt tolerant rootstock (Mt56, Cherry tomato, Solanum incanum and TKA). KALRO Project Technical Report.

Warschefsky, E. J., Klein, L. L., Frank, M. H., Chitwood, D. H., Londo, J. P., von Wettberg, E. J., et al. (2016). Rootstocks: diversity, domestication, and impacts on shoot phenotypes. Trends Plant Sci. 21, 418-437. doi: 10.1016/j.tplants.2015.11.00 